\title{
石川県輪島市大沢の生活地名と空間構造の関係
}

\section{A Study on the Relationship between Place Names with Life and Spatial Structure of Inhabitants in Osawa, Wajima, Ishikawa, Japan}

\author{
本多 秀行* 荒井 歩** \\ Hideyuki HONDA Ayumi ARAI
}

\begin{abstract}
Place names with life are defined as "names for land or space that are internally shared by the resident population in daily life”.The purpose of this study is to examine the spatial structure of villages on cultural landscape. By employing place names with life, we investigate the characteristics of distribution patterns on land uses. In the present study, we gathered and organized place names with life in Osawa, a traditional village in Wajima City, Ishikawa Prefecture, Japan. Results show ninety-one (91) place names with life. We then analyzed the village spaces having place names with a focus on topography and land use, and classified them into six (6) types, an easy slope with rivers on either side, a steep slope, planation surface that is surrounded by hills on two sides, yatsu on a small scale, planation surface that faces toward the sea, coastal sea area. The results clarified the characteristics of village spaces having place names as well as the spatial structure in the study location. We also discussed the possibility of using place names with life in the light of classifications on cultural landscape.
\end{abstract}

Keywords: place name, spatial structure, land use, cultural landscape, Wajima City キーワード：地名，空閒構造，土地利用，文化的景観，輪島市

\section{1. 研究の背景と目的}

近年，生業に基づく地域固有の景観を保全することの重要性が 指摘され 1)，日本では 2004(平成 16)年の文化財保護法の改正に より「文化的景観」が文化財の新しいジャンルとして規定された。 篠原 (2009) は文化的景観を「表出された景観」と表現し，景観を 守るためにはその景観を支えている人間の土地との関わり方につ いて言及する必要性を指摘している 2)。具体的には文化的景観保 存調查において「本質的な価值の把握」を目的する「景観単位の 区分」，「構成要素の特定」，「景観単位と構成要素の相互の有機的 関係の把握」を実施する必要がある 3 )。

「景観単位」とは, (1)地形・植生等の自然, (2)土地利用の歴史, (3)地域の生活または生業により形成された現在の土地利用, に基 づきある一定の特徵を示す区域を指寸ものである 3)。2011(平成 23) 年 9 月現在, 重要文化的景観として 29 件が選定されているが, 選定地における「景観単位」の区分状況は多様である 4)。ツバキ 林・棚田といった特定の生業の場を景観単位とした選定地 5)，地 形・植生，生業に関連する構成要素の状態を基本に景観単位を細 かく区分した選定地 ${ }^{6)}$ 等が存在する。区分の現状を鑑みると, 自 然環境亡土地利用単位区分の関係分析における客観的指標の必要 性がうかがえた。

文化的景観地には，居住者が土地を利用する際に地域を区分す るために使用してきた旧来からの地名が現存する。地名は，日常 的に用いる共通の呼称として, 人間の営為, 活動に対応した土地 との関わり方の指標と捉えることができる7)。そこで本研究は, 地名を指標とした集落の空間構造の整理が，文化的景観保存調査 に必要とされる「景観単位」の把握手法に活用できるのではと考 えた。

従来, 地名を対象とした研究は民族学, 地理学, 建築学, 造園 学等の分野で数多く行われてきた。笹谷ら (1985，1990)や寺門 (1990)の研究は, 空間言語としての地名に着目し，村落・集落空

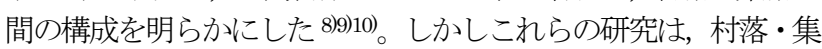

落空間の形成原理の追求を目的とする。山崎・重村らは, 1983 年に「生活地名」の概念を提示し, 生活地名を指標として生活空 間の特徵解明を目的とする一連の研究を展開している 7)11。本研 究では，山崎らが定義した「日常生活圏のなかで，居住者集団の 内部で共有している土地・空間に対する呼称」である生活地名を 活用し, 文化的景観地における空間構造の把握を目的とする。さ らに文化的景観保存調查において生活地名を景観単位の区分指標 として活用する可能性を検討した。なお，本研究の目的や地名の 一般的な分類や解釈をそのまま特定の地域に用いることは適切で はないことを考慮し，地名の語源分析は割愛した7)。

\section{2. 研究の方法}

\section{（1）対象地の選定}

「農林水産業に関連する文化的景観の保護に関寸る調查研究」 (2003)において二次調査対象に選定された石川県輪島市大沢集 落を本研究の対象地とした ${ }^{12)}$ 。大沢集落は石川県輪島市の北西部 に位置し, 人口 213 名, 世帯数 81 戸 $(2005)$ の 60 歳以上が人口 の 56\%を占める集落である。居住地は日本海に接して立地し，そ の後背には急峻な地形を活かした耕作地が約 $4.5 \mathrm{~km}$ にわたり続い ている。大沢集落は日本海からの特異な季節風への対策を施しな がら生活を営み続けてきた。居住地全体を囲むように設置されて いる防風柵「間垣」も対策のひとつである 13)。伝統的間垣の壁体 材には「ニガタケ」と呼ばれるメダケが用いられ，集落内には二 ガタケ (メダケ)の供給地が点在する ${ }^{14)}$ 。里山里海の資源を活かし た半農半漁の生活による文化的景観が評価されている ${ }^{15)}$

\section{（2）生活地名の採取}

生活地名および生活地名に対応寸る場所(以下，生活地名の場 所）と範囲を文献調査およびヒアリング調査から整理した。土地区 分の最小単位を表字名は公図・公簿, 村史, 市史から, 生活地 名はヒアリングおよび市史, 村史, 既往文献等を用いて採取した 16)17)18)。ヒアリング調査は 2009 (平成 21) 年 9 月，2010(平成 22)

\footnotetext{
*株式会社フォーラムエイト **東京農業大学地域環境科学部
} 
年 2 月, 7 月にかけて居住者計 9 名に対して数度にわたり行った。 事前の文献調査で整理した字名および生活地名の一覧表，大沢集 落の白地図, 現地の写真, 公図を用い, 字名と生活地名の照合を 併せて行った。また地名の由来や土地利用形態およびその恋化等 も聞き取った。ヒアリング調査の被験者は，大沢町区長および輪 島市教育委員会から紹介された 50〜80 歳の居住者とした。

\section{（3）生活地名の分布状況の整理}

採取した生活地名の場所や範囲を地図上におとし，生活地名分 布図を作成した。なお上述のヒアリング調査の結果，公図による 字名は生活地名として用いられていることが確認できたため, 生 活地名として扱うこととした。

整理された生活地名の場所を含む大沢集落全域において, 2010 (平成 22)年 2 月 9 月にかけて, 土地利用形態およひ利用状 況，水系の有無，道の有無，植生を現地踏査により確認した。ま た, 踏査結果と生活地名分布図を照らし合わせ, 生活地名の場所 と範囲の整合性を確認した。

\section{（4）集落における空間構造の特徵把握}

生活地名の場所の地形, 水系に着目して整理し, 地形タイプの 分類を行った。さらに生活地名の分布特徴を分析し，大沢集落に おける空間構造の特徵を明らかにした。

\section{3. 結果および考察}

\section{（1）生活地名の分布状況}

大沢集落全域から 94 件の生活地名を採取した。うち生活地名 の場所が確認できたのは 91 件であった。場所が確認できなかっ た 3 件は, 公簿に記載されているが場所が特定できないものだっ た。ヒアリング調査からも，「相続はしたが利用していないので場 所が分からないといら事例が確認された。

さらに現地踏査および文献調査により, 農地, 家屋, 神社仏閣, 河川，道等の現況を確認しベースマップを作成した。その上に
ヒアリング調査から得た生活地名の場所と範囲をおとし，生活地 名分布図を作成した(図一 1)。生活地名分布図内にはヒアリング 調查で得た生活地名をカタカナ表記で, 公図の字名と生活地名が 一致した生活地名は漢字表記で記した。

\section{（2）生活地名の分布特徵}

生活地名の場所における地形，水系を整理・分類した。その結 果, (1)地形の両端に水系がある斜面地(以下，タイプI), (2)一方 向の斜面地(以下，タイプII), (3)二面の斜面地に囲まれた幅 100 $\mathrm{m}$ 以上の平坦地(以下，タイプIII), (4)二面または三面を斜面に挟 まれた狭小な谷津(以下，タイプIV), 55海に面した平坦地(以下, タイプV), (6)海(以下, タイプVI)の 6 つの地形タイプに分類さ れた(図一2)。次に生活地名を整理し, 地形タイプ, 斜面方向, 土地利用形態, 居住地からの距離等から, 生活地名の分布特徴を 分析した(表一 1$)$ 。

1)居住地周辺の生活地名

居住地周辺の生活地名は, 居住地南側(図-1, 表-1 中の記号 $\mathrm{B})$, 居住地東側(図一 1 ，表-1 中の記号 $\mathrm{E}$ )で多く確認された。

居住地南側の生活地名は, 居住地から $1 \mathrm{~km}$ 以内の位置のタイプ I 上に段畑が形成された場所に多く存在する。居住地からのアク セス路は，人ひとり通れる程度の急な未舗装路しか存在しない。 以前は水田利用が行われていたが，現在は畑地一の転用および耕 作放棄が進んでいる。居住地近傍の後背山ながら居住地との境に は標高差 $50 \mathrm{~m}$ 以上のゴンデブラと呼ばれる急斜面地が存在し, 居 住地内から農地は見えない。「以前はゴンデブラがニガタケ(メダ ケ）供給地だった」,「水田があった頃は農地端のミヤノウエにイ ナハザ(ハザギ)が並び，海風でコメを乾燥させていた」等のヒア リング結果から土地利用形態の変化が読み取れた。平坦地を表す タイラ, ヒラを含む生活地名がみられ，畑地や山林の土地利用が 行われている。なお，字名と生活地名が一致する傾向にあった。

一方，居住地東側の生活地名は，居住地から $1 \mathrm{~km}$ 強までの位置

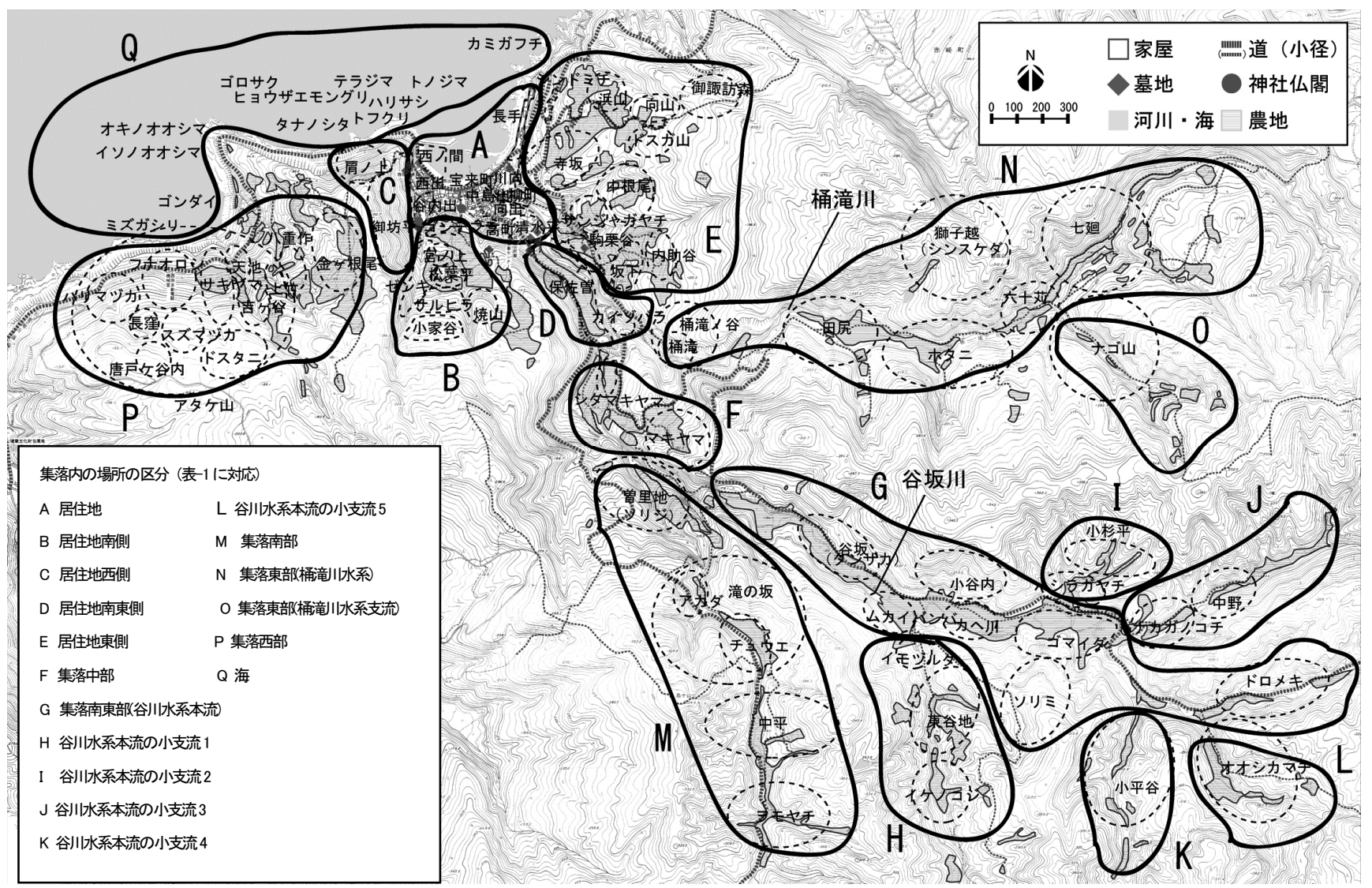

図-1 大沢集落の生活地名分布図 
表一1 大沢集落における生活地名の分布特徴

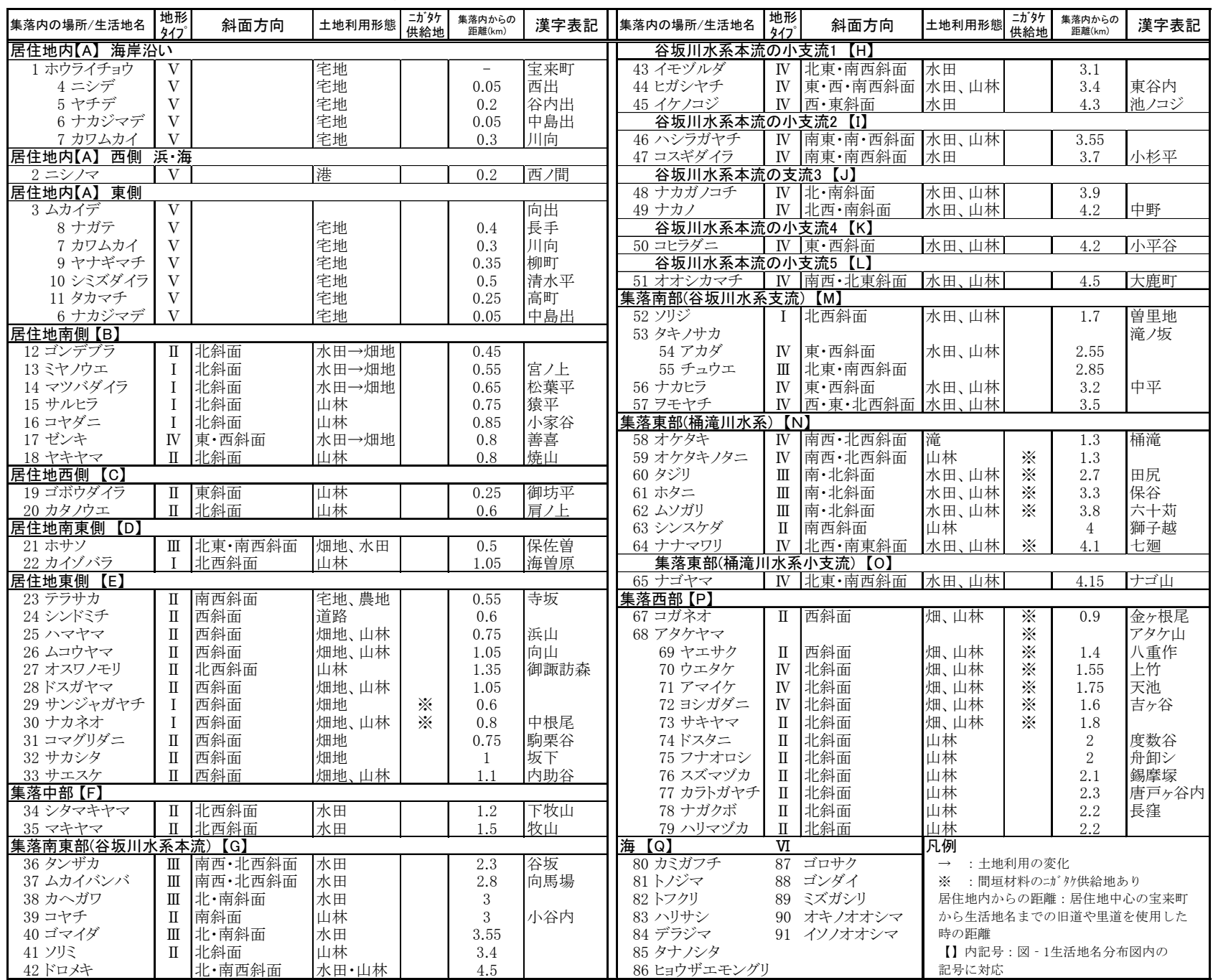

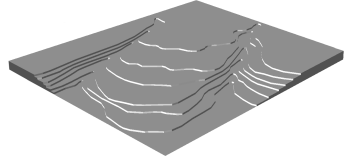

地形モデル I （地形両側に水系がある斜面）

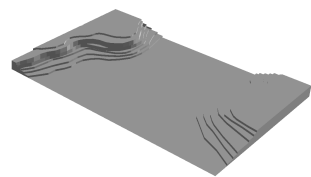

地形モデルIII (二面の斜面地に囲まれた 幅 $100 \mathrm{~m}$ 以上の平坦地)

※地形モデルV (海に面した平坦地)，地形モデルVI(海) は平坦地の模式应 化であるため省略した。

\section{図一2 地形タイプの模式図}

の西斜面，タイプII上に形成された段畑に多くみられた。居住地 からアスファルト舗装が施された農道が整備されアクセスが容易 であり，耕作放棄地も少ない。また居住地内から眺望できる農地 である。斜面上部にヤマ，才が付く生活地名が複数存在し，烟地 と山林の土地利用が行われている。斜面下部には，タニ，ヤチを
含む生活地名がみられ畑地利用がなされている。同一水系を含有 するサンジャガヤチ，ナカオネはニガタケ供給地であった。

なお居住地南東側(図-1, 表- 1 中の記号 D) と集落中部(図一1, 表一 1 中の記号 F) でも, 数は少ないが現在も耕作が続けられてい る農地で生活地名が確認された。居住地南東側の農地はタイプ I とタイプIIIに畑が立地し，斜面や山腹を指寸とされるソを含む生 活地名が存在する。また, 集落中部の農地は比較的急なタイプII 上に棚田が作られ，ヤマが付く生活地名が名付けられていた。 2)集落南東部・集落南部の生活地名

集落南東部の生活地名は, 谷坂川水系本流周辺(図-1, 表 -1 中の記号 G) と谷坂川水系本流小支流周辺 (図-1, 表-1 中の記号 H,I,I,J,K,L) に, 集落南部の生活地名は谷坂川水系支流周辺(図一 1，表一 1 中の $\mathrm{M}$ ) に分布していた。

谷坂川水系本流周辺の生活地名は，居住地力ら $2 \sim 3 \mathrm{~km}$ の位置 のタイプIII上に緩やかな棚田が形成されている場所に多くみられ た。居住地からの距離および標高差があるものの, 急峻な斜面地 が多い大沢集落において比較的まとまった平坦地が確保できる場 所である。居住地から農道が整備されており，水田の耕作状態は 比較的良好である。谷坂川沿いには，タ二，カワ等を含む生活地 名が確認され，ムカイバンバ，ゴマイダ等，場所の位置関係や状 態を表した生活地名もみられた。また字名と一致しない生活地名 が多く確認された。

谷坂川水系本流小支流周辺および谷坂川水系支流周辺の生活地 


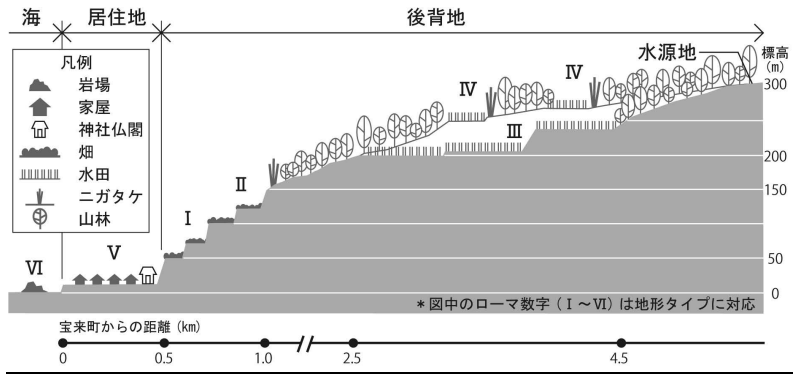

図-3 大沢集落の空間構造(模式図)

表-2 大沢集落の空間構造の特徵

\begin{tabular}{|c|c|c|c|c|c|}
\hline 空間構造区分 & 地形タイプ & 主な生業 & 土地利用形態 & \begin{tabular}{|c|}
$\begin{array}{c}\text { 土地利用に関連した } \\
\text { 特徵的な要素 }\end{array}$ \\
\end{tabular} & 生活地名の特徵 \\
\hline 海 & $\overline{\mathrm{VI}}$ & 漁業 & 魚場 & 岩場, 浜, 港 & 大半の岩場に命名 \\
\hline 居住地 & $\mathrm{V}$ & & 居住 & \begin{tabular}{|l|l} 
間垣 \\
神社仏閣
\end{tabular} & \begin{tabular}{|l} 
形成過程に由来 \\
位置関保に由来
\end{tabular} \\
\hline \multirow{5}{*}{ 後背地 } & I & 農業 & 畑 (以前は水田) & 段畑, 水系 & 緩斜面 : タイラ, ヒラ \\
\hline & \multirow[t]{2}{*}{ II } & \multirow[t]{2}{*}{ 農業 } & $\frac{\text { 山林 }}{\text { 山林 }}$ & 二ガが 外(ダケ) 供給地 & 斜面上部：ヤマ,才 \\
\hline & & & 畑 & 段畑, 水系 & 斜面下部：タニ, ヤチ \\
\hline & III & 農業 & 水田 & 棚田, 水系 & $\begin{array}{l}\text { 河川沿い: タニ, カワ } \\
\text { 位置関係や状態に由来 }\end{array}$ \\
\hline & IV & 農業 & $\begin{array}{l}\text { 水田 } \\
\end{array}$ & 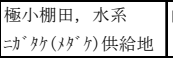 & \begin{tabular}{|l|} 
山林十水田の範囲に \\
命名: ヤチ, コチ, タ=
\end{tabular} \\
\hline
\end{tabular}

名は, 居住地から 3〜4 kmの位置のタイプIV上に形成された山林 と小規模な棚田がある場所で確認された。狭小な谷津地形上の山 林と水田を合わせた範囲に生活地名が付けられる特徵がみられ， ヤチ, コチ, タニが付く生活地名が多く存在する。また旧道整備 のための赤土を確保した場所にはアカダという土地の利用内容を 示寸生活地名がみられた。

3)集落東部の生活地名

集落東部の生活地名は，桶滝川水系周辺(図一-1, 表一 1 中の記 号 $\mathrm{N} ， \mathrm{O})$ に分布していた。集落から 3〜4kmに位置し，タイプIII またはタイプIV上に立地した水田と山林による構成の比較的広い 範囲に対して命名されている。字名と生活地名が一致する傾向に あった。また多くの生活地名内に二ガタケ(メダケ)供給地が存在 していた。

4)集落西部の生活地名

集落西部(図 -1 , 表 -1 中の記号 $\mathrm{P})$ の生活地名は, 海沿いの斜 面地に多くみられた。居住地から 1 $2 \mathrm{~km}$ の位置に分布し, 北斜 面のタイプII またはタイプIV上に形成された山林，または山林と 畑の場所に存在する。海沿いの県道が整備されるまでは, 居住地 西側の尾根を越える旧道によってアクセスされていた。大沢集落 内で一番大きな二ガタケ(メダケ)供給地があり，アタケヤマとい う総称がニガタケ(メダケ)供給地を指寸こともある。

5) その他の生活地名

居住地(図-1, 表- 1 中の記号 $\mathrm{A}$ ) はタイプV上の平坦地に立地 しており，集落の形成由来や位置関係に依拠した生活地名が存在 する。字名と生活地名が全て一致していた。海域(図-1, 表-1 中の記号 Q)の生活地名は, 海岸近傍の岩場に対して名付けられ たものであった。岩ノリ漁等の関係から大小関わらず岩場の大半 に生活地名を付ける必要があったとされる。

\section{（3）集落における空間構造の特徵}

生活地名の分布特徴を基に, 特に地形タイプと土地利用形態の 関係を鑑みながら，空間構造の模式化を行った(図一 3 ，表一2)。

大沢集落における空間構造は, 海, 居住地, 後背地に大別され た。海と後背地は半農半漁の生業との関係が深く, 漁業に関係す る場所や農業に関係する場所に対して生活地名がつけられていた。 生活地名は地形形状に由来すると考えられるものが多く確認され た。限られた土地を地形タイプに応じて，段畑，棚田と細かく使
い分ける農業や漁業に関する土地利用のあり方が，地形タイプを 原単位とした生活地名として表出し, 大沢集落における空間構造 の骨格を形成したと推察される。

一方, 山林単独につけられた生活地名は居住地南側, 居住地西 側および集落西部の一部にみられるだけであった。林業は大沢集 落における主幹生業であったことはない。また大沢集落の厳しい 地形や季節風・積雪等の自然条件により生活を営む家屋は間垣に 囲われたタイプ $\mathrm{V}$ 上の居住地内のみに立地する。同様に共同施設 や信仰空間も居住地内に集約され，集落全体に分布していない。 これらの状況が林業や信仰に関連する生活地名の少なさに表れて いると考えられた。

\section{4. まとめ}

本研究では大沢集落における生活地名を採取し, 地形タイプと 土地利用形態との関係性を基に生活地名の分布特徵を整理した上 で，大沢集落の空間構造を明らかにした。

最後に文化的景観保全調查において生活地名を景観単位の区分 指標として活用する可能性を検討する。本対象地では, 文化的景 観の特徵である生業・生活を規定する自然環境（地形，水系）と 土地利用形態の関係が生活地名の分布に基づく集落の空間構造に 顕在化していた。このような文化的景観地の場合, 生活地名を土 地利用区分単位と捉え, 生活地名の集積を景観単位として用いる ことで, 既存の景観単位設定事例に比べてより詳細な景観単位検 討が行えると考える。

\section{補注及び引用文献}

1) UNESCO(2008):Operational Guidelines for the Implementation of the World Heritage Convention(WHC.08/01 January 2008)

2) 篠原修(2009): 時代を画寸文化的景観の概念とその展開:ランドスケープ研究，73(1) 3) 平成 17 年 4 月 26 日付け 17 庁財第 33 号の文化庁文化財部長通知「文化財保護法の 一部改正に伴う制度の運用方針について」の「第 1 重要文化的景観の選定制度の運 用についてにうち,「2 文化的景観保存計画の策定にあたっての留意事項

4) 文化庁: 〈http://www.bunka.go.jp/bunkazai/shoukai/keikan.html>, 2011. 12.12 閲覧

5) 長崎県 : < http://www.pref.nagasaki.jp/koho/hodo/upfile/20110520115255.pd子>, 2011. 12.12 閲覽

6) 奈良文化財研究所(2011):四万十川流域 文化的景観研究, 奈良文化財研究所学報第 89 冊, 7-52

7) 山崎寿一重村力(1993): 生活地名からみた中久保集落の空間意識の構成: 日本建築 学会計画系論文報告集:第442 号, 133-141

8）笹谷康之他(1990): 小地名相互の位置関倸に基づいた村落空間講師の研究:造園䧱誌, 53(5), 293-298

9）笹谷康之他(1985):農村集落の民族空間構成に関寸る研究: 造園杂倞志, 48(5), 318-323 10）寺門征男(1990): 空間言語(地景名)からみた集落空間の組織化と構成現地につい て:日本建築学会計画系論文集，第416, 55-65

11）重村力他(1983)：ある集落の研究\#6,7 : 日本建築学会大会学術講演梗概集, 1939-1942

12）文化庁文化財部記念物課(2003):農林水産業に関連する文化的景観つ保護に関する 調查研究(報告)

13）荒井歩他(2009): 石川県輪島市大沢地区・上大沢地区における間垣の特徽について: 造園技術報告集，№.5, 140-143

14）荒井歩他(2011): 石川県輪島市大沢・上大沢における間垣管理の工程: 造園技術報告 集, №.6, 94-97

15）輪島市文化課(2006): 平成 17 年度文化的景観・民族技術調査報告書 「輪島」: 石川 県輪島市, 53-99

16）輪島市地籍図「大沢町」

17) 伊藤和吉(1960):西保村史:輪島市西保公民館, 516pp

18）輪島市史編篹専門委員会(1976):輪島市史 : 輪島市, 937pp 